\title{
MENGENAL BATIK SLOGAN KLASIK
}

\section{Estika Amalia Anggreni}

Universitas Nahdlatul Ulama Sidoarjo

Email: estikaanggreni95@gmail.com

\section{Batik sogan klasik}

Batik sogan klasik merupakan salah satu jenis batik di Indonesia bernuansa klasik memiliki unsur tradisional dengan warna dominan variasi dari warna coklat.Dinamakan batik sogan karena pada awal mulanya, proses pewarnaan batik ini menggunakan pewarna alami yang diambil dari batang kayu pohon soga tingi. Batik sogan memang jenis batik yang identik dengan daerah keraton Jawa yaitu Yogyakarta dan Solo, motifnya pun biasanya mengikuti pakem motif klasik keraton. Sogan Yogya dan Solo juga dapat dibedakan dari warnanya.

Biasanya sogan Yogya dominan berwarna coklat tua-kehitaman dan putih, sedangkan sogan Solo berwarna coklat - oranye dan coklat.Batik sogan yang klasik ini memang selalu banyak peminatnya dan langgeng tanpa mengenal musim, selalu ada pecinta jenis batik ini. Dipakai pada acara formal,baju batik sogan ini juga bagus dikenakan saat santai atau kasual. Walaupun ada batik pesisiran yang lebih dinamis baik warna maupun 
motifnya yang kontemporer dan eksotis. Harga batik sogan klasik mencapai Rp.200.000.

\section{Budaya batik sogan klasik}

Sejak diresmikan oleh UNESCO sebagai salah satu kekayaan dan kebudayaan asli Indonesia. Batik manjadi primadona di pasar negara kawasan Asia dan Eropa.Salah satu batik yang menjadi primadona itu adalah jenis batik tulis sogan. Dalam rilisan antara news ( 20/9/2010), menurut pengelola sogan haritage di desa Rejodani, kecamatan Ngaglik, kabupaten Sleman, Daerah Istimewa Yogyakarta, Lisa Sabung, batik tulis dengan pewarna alami ini tidak hanya dijual ke berbagai daerah di Indonesia, tetapi juga diekspor ke beberapa negara di kawasan Asia dan Eropa.

"Batik tulis sogan sampai sekarang sudah menembus pasar negara di Asia seperti Malaysia dan Singapura, dan Eropa serta Kanada," katanya. Dia mengatakan tidak hanya batik tulis dengan pewarna alami yang diekspor, tetapi juga batik tulis dengan perwarnaan sintetis atau menggunakan bahan kimia yang juga laku di pasaran Asia serta Eropa. Sogan haritage mempekerjakan 53 orang, semuanya ibu rumah tangga dari sekitar desa setempat. "Dengan jumlah tenaga kerja sebanyak itu, kami mampu memproduksi kain batik tulis sogan dengan pewarnaan alami maupun sintetis rata - rata 500 potong per bulan," harga kain batik tulis sogan, baik yang menggunakan pewarna alami maupun pewarna sintetis antara Rp200.00 hingga 
Rp300.000 per potong. Mengapa batik jenis batik sogan ini menjadi primadona dan dicari-carioleh para peminat dari mancanegar? ya batik tulis sogan batik yang merupakan cikal bakalnya kain batik ini nuansanya sangat klasik dengan warna dominan variasi dari warna coklat. Bernama batik sogan karena pada awal mulanya, proses pewarnaan batik ini menggunakan pewarna alami yang diambil dari batang kayu pohon soga tinggi. Soga merupakan nama tumbuh-tumbuhan dari keluarga papilionaceae dan mempunyai warna kuning penggunaan pewarna alami ini menyebabkan warna batik terasa lebih sejuk.

Batik adalah salah satu ciri yang khas setiap daerah namun di setiap daerah memiliki berbagai macam-macam batik yang menarik dan bermacammacam motif di salah satu kota di Sidoarjo (Yuniarti et al., 2018). Batik sogan klasik jenis batik yang jadi primadona dikawasan Asia dan Eropa karena batik sogan terbuat dari bahan yang tidak menggandung bahan kimia sehingga banyak yang suka dengan batik sogan klasik.

\section{Sejarah teknik batik sogan klasik}


Dr.G.Prof.Uffaer, peneliti di Hindia-Belanda ber pendapat bahwa teknik membatik kemungkinan diperkenalkan dari India atau Srilanka pada abad ke-6 atau ke-7. Masih soal opini Rouffaer. Walau ia mengatakan teknik ini hasil adaptasi budaya impor, ia juga menulis pola gringsing sudah dikenal sejak abad ke-12di Kediri, Jawa Timur. Pola tersebut hanya bisa dibentuk dengan menggunakan alat canting. Akhirnya kesimpulan doktor Belanda ini adalah canting ditemukan di Jawa pada masa sekitar itu. Tidak ada budaya " orisinil "dalam khasanah sejarah. Namun pembentukan tradisi baru akan menghasilkan bentukan budaya yang juga " baru ".

Demikian pula pada batik memang ada asimilasi budaya yang datang ke tanah Jawa. Tapi pada akhirnya, bila benar canting ditemukan oleh masyarakat Jawa, maka batik menjadi budaya baru. Batik adalah milik penduduk kepulauan Nusantara ini. Opini J.L.A. Brandes, arkeolog Belanda, dan F.A. Sutjipto, sejarawan Indonesia. Mereka percaya bahwa tradisi batik adalah asli dari daerah seperti Toraja, Flores, Halmahera dan Papua. Perlu dicatat bahwa wilayah tersebut bukanlah area yang dipengaruhi oleh Hinduisme, tetapi diketahui memiliki tradisi kuno membuat batik.Teknik batik pertama kali dikenalkandari India pada abad ke-6 atau ke-7. Pola juga pertama kali pada abad 12 di Kediri dengan menggunakan canting.

\section{Corak pada batik sogan klasik}


Batik sogan adalah jenis batik yang identik dengan daerah keraton Jawa yaitu Yogyakarta dan Solo, motifnya mengikuti pakem motif klasik keraton. Berdasarakan asalnya batik sogan dibedakan menjadi batik sogan Yogya dan Solo juga dapat.Biasanya yang membedakan adalah batik sogan Yogya dominan berwarna coklat tuakehitaman dan putih, sedangkan batik sogan Solo berwarna coklat-oranye dan coklat.Batik sogan yang klasik ini memang selalu banyak peminatnya dan langgeng tanpa mengenal jaman, selalu ada pecinta jenis batik ini, meski sekarang ini banyak motif batik modern.

Keunikan lainya dari batik sogan ini adalah berbeda dengan batik yang menggunakan pewarna kimia, batik yang diproduksi dengan pewarna alami akan sulit dicari kembaranya. Keunikannya yang sulit untuk menciptakan warna yang sama meski dalam waktu pewarnaan yang bersamaan, memberi kesan eklusif tersendiri bagi batik sogan. Kain yang satu dengan kain yang lainnya meski dalam satu waktu pengerjaan yang bersamaan hasilnya pasti ada bedanya.

Namun justru karena itu, hasil karya ini lebih disukai bagi pemakai batik yang berselera tinggi. Selain itu ciri khas lainya dari batik sogan adalah jika dilihat sekilas,tidak ada perbedaan antara batik yang menggunakan pewarna kimia dengan batik sogan.Namun bila diamati lebih teliti, terdapat perbedaan di kedua jenis batik ini yaitu pada batik sogan asli pola pada warna terang atau warna coklat 
terang tidak akan bisa terlihat bersih polos, melainkan akan terlihat seperti ada serat warna coklat. Inilah ciri khas yang tak bisa ditemui pada batik yang menggunakan warna kimia.Kombinasi warna batik sogan tidak terlalu jauh dari warna coklat.Kombinasi warnanya biasanya coklat muda, coklat tua, coklat kekuningan, coklat kehitaman dan coklat kemerahan."Kayu secang menimbulkan warna kemerahan.Kayu tingi kehijauan.Kayu jambal hitam kecoklatan, dan sebagainya.Kalau dicampur akan memunculkan warna lain" jelas Harno, pemilik rumah produksi batik. Di desa Pilang kecamatan Masaran.

\section{Prosedur pembuatan batik sogan klasik}

1. Tahap pertama

Pewarnaan warna dasar yaitu biru tua, hasil dari tahap pertama ini disebut kain batik kelengan yang berwarna biru tua. Tahap awal batik terdiri dari nyorek, membatik dengan malam, nembok yaitu mengeblok dengan malam, medel(nyelup warna biru tua dengan bahan nilo) terus dijemur dengan cara diangin - anginkan, tidak terkena matahari langsung, proses medel dilakukan berkali kali sampai didapatkan warna biru yang diinginkan, setelah proses medel selesai dilakukan pengerokan, setelah dikerok malamnya dicelup dengan air panas, proses tahap awal selesai hasil tahap ini dinamakan kain kelengan prosesnya disebut mbironi. 
Kain yang kelengan yang berwarna biru tua dan putih ini juga sudah pantas bisa digunakan sebagai bahan pakaian.Satu pewarnaan warna dasar telah selesai, batik setengah jadi kelengan diproses lagi ke tahap ke dua dengan pencelupan warna coklat tua

1. Tahap kedua

Pewarnaan warna coklat tua, kain kelengan yang berwarna biru tua, dibatik dan ditembok lagi, kemudian dicelup dan dijemur lagi berulang kali dengan warna coklat yang disebut soga, prosesnya disebut nyogan, nyogan dan menjemur dilakukan berulang ulang 20-30 kali sampai didapatkan warna coklat yang mateng (tua), proses nyelup berulang ulang tahap kedua ini sama dengan proses tahap 1.

2. Tahap ketiga

Hasil tahap 2 dikerok dan dilorot malamnya, warna putih hasil penutupan malam diwarnai dengan warna coklat muda atau warna lain, kalau batik klasik cukup warna putih dicelup soga dan dijemur berulang 2-3 kali saja. Batik modern dan kontemporer memberikan sentuhan warna lain merah, kuning, hijau dll. Pewarnaan warna lain tidak dicelup lagi tapi cukup dicolet kemudian dijemur, dicolet dandijemurnya juga berulang ulang kali seperti tahap - tahap lainnya. Semua proses tahap kedua dan ketiga ini 
biasa disebut proses mbabar. Ketelitian seluruh proses mbabar, proses pencelupan warna soga dan warna lain, bahan dan kwalitas pewarna, mateng tidaknya warna akan membedakan harga produk.

\section{Tahap akhir}

Pada tahap akhir perlu penguncian terhadap warna yang telah dicelup dan dicolet, kain batik hampir jadi tapi masih mudah luntur saat dicuci, agar tidak mudah luntur, proses terakhir dikunci atau mematikan semua warna yang telah dicelup, penguncian dilakukan dengan bahan jeruk, tawas dan bahan alami lainnya, setelah dikunci baru dijemur, sampai proses ini pembuatan kain batik telah selesai. Penjelasan diatas adalah untuk batik tulis, untuk batik cap dan kombinasi kurang lebih proses dan tahapnya sama dengan diatas.

Jika ada 3 warna dalam batik, misal warna merah, hijau, biru. Saat pencelupan warna merah, maka gambar warna hijau dan biru harus ditutup dengan malam dengan cara menembok (ngeblok dengan malam). Kemudian malamnya dilorod dibersihkan dengan cara dikerok atau dicelup dengan air panas, saat pencelupan warna hijau, maka gambar warna merah dan biru ditutup malam dengan nembok, demikian seterusnya prosesnya sama saat pencelupan warna merah tadi. Jika ada warna $A, B, C, D$, saat pencelupan warna $A$, maka 
warna $B, C, D$ harus ditutup dengan malam, saat pencelupan warna $B$, maka warna $A, C, D$ harus ditutup dengan malam, sehabis ditembok kemudian dicelup warna tertentu terus dilorod malamnya, demikian seterusnya dilakukan berulang kali.

Sedemikian rumit proses pembuatan sebuah kain batik, membuat kain batik menjadi lebih berkelas dibanding dengan kain printing yang sekali jadi dan mudah dicetak, berapapun warna yang ada. Proses menjadi lebih rumit lagi jika proses pewarnanya mengggunakan warna alam dari akar, biji, kayu, daun tumbuh - tumbuhan, karena proses pencelupan warna alam harus dilakukan berpuluh puluh kali dan otomatis menambah sulit dan menambah prosentase kegagalan produk, untuk itu batik warna alam harganya juga lebih mahal.

\section{Prosedur pembuatan batik}

Beberapa teknik pokok batik, yaitu batik tulis dan batik cap.Batik tulis adalah batik yang dikerjakan dengan canting tulis. Batik cap adalah batik yang dikerjakan dengan teknik cap. Namun ada juga batik yang dikerjakan dengan gabungan dua teknik tersebut, yaitu gabungan teknik tulis dengan cap.Batik seperti ini disebut dengan batik kombinasi.

Banyaknya proses pengerjakan batik tergantung dari jumlah pewarnaan (celup). Batik monokrom dikerjakan dengan sekali proses (mbabar sepisan). Untuk batik dengan dua warna dikerjakan dengan dua kali proses (mbabar pindo). Sementara 
batik tiga warna dikerjakan dengan tiga kali proses atau disebut batik tiga negeri sebagai salah satu ciri batik pesisiran. Setiap proses pembatikan pada dasarnya mengalami proses yang sama, sebagai berikut :

1. Pemalaman

Membatik adalah pekerjaan yang saling berurutan, artinya satu langkah dapat dikerjakan jika langkah sebelumnya telah selesai dikerjakan.Setiap tahap dapat dikerjakan oleh orang yang berbeda. Sepotong mori tidak dapat dikerjakan oleh beberapa orang dalam waktu yang sama untuk beberapa tahapan.Tahapan pemalaman dengan canting tulis adalah sebagai berikut :

a. Membuat Kerangka

Membuat kerangka (mola), adalah membuat kerangka pola secara garis besar.Pembuatan pola dengan menggunakan pensil disebut mola. Pembuatan pola dengan pensil hanya untuk batik tulis, sedangkan untuk batik cap tidak dibutuhkan pembuatan pola dengan pensil. Hal itu karena motif hias sudah ada pada permukaan canting cap.

Pembuatan pola tanpa melalui pembuatan pola dengan pensil atau membuat pola langsung dengan menggunakan canting disebut dengan istilah ngrujak.Pekerjaan ini 
hanya dilakukan oleh orang yang sudah mahir (profesional).Dan hasil pekerjaan ini disebut batikan klowongan atau klowongan.Bentuk batik klowongan adalah motif pokok.Canting yang digunakan adalah canting klowongan yang memiliki cucuk ukuran sedang.

b. Ngisen - isen

Ngisen-isen adalah melengkapi pola yang masih berbetuk kerangka( klowongan) atau motif pokok dengan motif isen-isen, seperti sawut, ukel, dan sebagainya. Ngisen-iseni menggunakan canting khusus seperti canting cecekan, canting prapatan, atau canting piton. Setiap pekerjaan ngisen-iseni memiliki nama sendirisendiri. Pemberian nama pada pekerjaan ngisen - iseni tergantung dari jenis canting yang digunakan.

Nama jenis canting diubah menjadi kata kerja dan dijadikan nama pekerjaan, sedangkan nama hasil pekerjaan diambil dari nama canting yang digunakan. Misalnya pekerjaan nyeceki adalah pekerjaan yang menggunakan canting cecekan. Hasil pekerjaannya disebut cecekan.Pekerjaan neloni adalah pekerjaan yang menggunakan canting telon.Hasil pekerjaannya 
disebut neloni.Pekerjaan mrapati dilakukan dengan canting prapatan. Hasil pekerjaannya disebut prapatan. Kain batik yang telah dikerjakan gambar kerangkanya (mola) dan dilengkapi dengan isenisennya disebut dengan nama reng rengan.

c. Nerusi

Pekerjaan nerusi merupakan pekerjaan penyelesaian kedua.Nerusi adalah membuat pola dan isen - isen di sebaliknya kain reng - rengan. Caranya adalah batik reng - rengan dibalik, kemudian di bagian belakang tersebut dibatik dengan pola yang sama dengan batikan reng - rengan. Dengan demikian, batikan bagian muka dan belakang kain mori akan sama. Proses ini sangat penting untuk membuat fungsi lilin malam sebagai perintang warna akan menjadi sempurna karena warna antarpola tidak merembes dan bercampur.

d. Nembok

Nembok dilakukan dalam batik dengan proses beberapa kali pewarnaan. Ketika sebuah batikan tidak seluruhnya akan diberi warna karena suatu bagian akan diberi warna lain maka bagian yang tidak 
akan diberi warna ditutup dengan malam. Pemalaman seperti ini disebut nembok.Cara nembok seperti membatik bagian tertentu dengan canting tembokan.Pekerjaan nembok biasanya menggunakan jenis malam dengan kualitas rendah.

e. Mbliriki

Mbliriki adalah proses nerusi, namun untuk bagian tembokan. Mbliriki memiliki fungsi yang sama dengan nerusi, yaitu membuat batikan dibagian belakangmori, namun berbeda bagian. Hasil pekerjaan

disebutblirikan.Seperti mbliriki blirikan juga menggunakan canting tembokan dan caranya seperti nemboki.

1. Teknik dan istilah pewarnaan batik

Proses selanjutnya setelah proses pembuatan pola yaitu pemberian warna. Pemberian warna ini pada tempat atau bagian kain yang terbuka sedangkan pada bagian kain yang tertutup lilin malam tidak terkena warna atau tidak berwarna.Oleh karena itu jumlah pemberian lilin malam tergantung dari jumlah warna yang digunakan.

Di dalam proses pewarnaan batik dikenal beberapa istilah. Macam macam istilah pewarnaan tersebut, 
antara lain medel, celupan warna dasar, menggadung, coletan atau dulitan, dan menyoga.

\section{a. Medel}

Medel adalah memberi warna biru tua pada kain setelah kain dicap klowongan dan di cap tembok atau selesai di tulis. Untuk kain sogan kerokan, medel merupakan warna pertama yang diberikan pada kain.Medel dilakukan secara celupan.Dahulu bahan yang dipakai untuk medel adalah nila dari daun indigofera (daun tom) karena cat pewarna ini mempunyai daya pewarnaan lambat sehingga celupan dilakukan berulang ulang.Selanjutnya untuk medel dipakai zat pewarna indogo synthetis. Cara pencelupannya sama dengan indigo alam. Medel dengan zat warna naphtol cara pencelupannya lebih cepat. Hal ini karena pencelupan hanya dilakukan satu kali.

b. Celupan warna dasar

Teknik celupan warna dasar digunakan pada proses membatik yang tidak dilakukan pada kain mori yang masih berwarna putih. Artinya ketika proses pemalaman kain sudah diberi warna dasar. Oleh karena itu 
batik ini sering disebut batik berwarna.

Batik - batik berwarna seperti batik Pekalongan, batik Cirebon, dan batik Banyumas tidak di wedel, tetapi sebagai gantinya diberi warna yang lain, seperti warna - warna hijau, violet, merah, kuning, orange, dan warna - warna yang lain. Agar warna dasar pada pewarnaan berikutnya tidak berubah atau tidak tertindih warna lain, maka perlu ditutup dengan lilin batik. Oleh karena itu zat warna yang dipakai adalah yang mempunyai ketahanan yang baik seperti indigosol, naphtol atau indanthreen.

c. Menggadung

Menggadung adalah menyiram kain dengan larutan zat pewarna.Kain diletakkan terbuka rata di atas papan atau meja, kemudian di siram dengan larutan pewarna.Cara pewarnaan ini menghemat zat warna, tetapi hasil warnanya kurang rata sehingga larutan cat itu diratakan dengan disapu - sapu.Pewarnaan batik secara menggadung ini dikerjakan oleh para pembuat batik Pekalongan untuk memberi warna pada kain batik sarung atau batik buketan. 
f. Coletan atau dulitan

Pewarnaan dengan cara coletan atau dulitan ialah memberi warna pada kain batik setempat dengan larutan zat warna yang dikuaskan atau dilukiskan di daerah yang diwarnai dengan dibatasai oleh garis - garis lilin sehingga warna tidak menerobos daerah yang lain. Biasanya untuk coletan dipakai cat rapid atau indigosol.Di daerah pantai utara Jawa, seperti Gresik, pewarnaan semacam ini disebut dulitan dan kain batik yang dihasilkan disebut kain dulitan.Hal ini sudah dikerjakan sejak dahulu.Di daerah Pekalongan, coletan ini banyak digunakan pada batik buketan.

g. Menyoga

Menyoga adalah memberi warna coklat pada kain batik. Untuk kain sogan Yogya dan Solo, menyoga merupakan pewarnaan terakhir. Dahulu warna coklat atau warna soga dibuat dari zat pewarnaan tumbuh tumbuhan, antara lain kulit pohon soga sehingga sampai sekarang mencelup batik dengan warna ini disebut menyoga dan warna coklat pada kain batik disebut warna soga. Warna soga dapat diperoleh dengan zat - zat warna dari tumbuhan yang 
disebut soga Jawa dan zat warna soga synthetis, seperti soga Ergan, soga Chroom, soga Kopel, zat warna Napthol, zat warna indigosol, atau kombinasi (campuran)dari beberapa zat warna tersebut.

Tahap pewarnaan ini tidak dapat dipisahkan dengan tahap pemalaman.Setiap tahapan diberi warna, seperti pewarnaan satu, pewarnaan dua, pewarnaan tiga dan seterusnya. $\mathrm{Di}$ dalam batik pewarnaan dengan satu warna dilakukan sekali proses yang disebut dengan babar sepisan (babar sekali). Pewarnaan dengan dua warna disebut babar pindo (babar dua kali) dan tiga kali pewarnaan disebut babar tiga negeri.

Pewarnaan teknik celup adalah mencelupkan seluruh bagian kain batik ke dalam larutan warna.Untuk penggunaan warna dari napthol dibutuhkan dua kali pencelupan.Celupan pertama disebut celupan napthol.Pada celupan pertama warna yang dikehendaki belum muncul. Baru pada celupan kedua warna akan muncul. Pencelupan kedua disebut penggaraman karena yang digunakan adalah zat kimia garam 
$(\mathrm{RC})$.Celupan kedua berfungsi untuk memunculkan dan menguatkan warna yang dikehendaki.

2. Penghilangan lilin (pelorodan)

Menghilangkan lilin (malam) pada batik dapat bersifat menghilangkan sebagian atau menghilangkan keseluruhan lilin. Menghilangkan sebagian atau setempat adalah melepas lilin pada tempat atau bagian - bagian tertentu dengan cara mengerok dengan alat sejenis pisau. Pekerjaan dengan cara mengerok ini disebut ngerok atau ngerik. Pekerjaan ini dilakukan setelah kain di wedel untuk batik sogan dari Solo atau Yogyakarta. Maksud dari pekerjaan ini ialah membuka lilin klowongan, dimana pada bekas lilin yang dikerok ini nantinya akan diberi warna soga.

Penghilangan lilin secara keseluruhan dapat dilakukan pada pertengahan maupun akhir proses pembuatan kain batik Penghilangan lilin secara keseluruhan disebut pelorodan. Pada batik Pekalongan proses ini sering dilakukan. Pelorodan yang dilakukan ditengah proses pembatikan biasanya dilakukan untuk memberikan warna lainpada jejak lilin yang dilorod. Pada bagian - bagian pola yang diinginkan, dibiarkan putih dicanting (ditutup) ditutup kembali dengan lilin. Sementara bagian 
lain yang akan diwarna tertentu dibiarkan tanpa ditutup lilin.

Pelorodan pada akhir proses pembuatan batik disebut dengan mbabar atau ngebyok. Pelepasan dilakukan dengan menggunakan air panas. Lilin akan meleleh dalam air panas sehingga terlepas dari kain. Untuk kain dengan pewarnaan dari bahan alam, air panas diberi kanji. Sementara untuk pelorodan kain batik dengan pewarnaan dengan warna sintetis air panasnya diberi soda abu. Lilin dapat dihilangkan dengan menyeterika. Penghilangan lilin malam dengan seterika dilakukan sebagai berikut ;

a. Siapkan meja kerja dengan alas koran bekas.

b. Siapkan pula kertas koran lain dan kertas tisu.

c. Letakkan kain batik yang akan dihilangkan lilin malamnya di atas kertas koran bekas. Di atas kain diletakkan kertas tisu beberapa lembar sesuai kebutuhan.

d. Letakkan lagi (di atas tisu) selembar kertas koran.

e. Setelah seterika panas, letakkan di atas kertas koran paling atas. Gosokgosokkan seterika beberapa saat.

f. Angkat kertas koran paling atas dan kertas tisu. Dengan pemanasan 
seterika tersebut, lilin malam akan meleleh dan menempel pada kertas tisu.

\section{Penutupan}

Batik merupakan salah satu kekayaan warisan budaya bangsa Indonesia. Batik adalah sebuah proses menahan warna dengan memakai lilin malam secara berulang-ulangdiatas kain.

\section{References}

https://batikpekalongan.wordpress.com/2007/10/31/ batik-sogan/

https://images.sudarjanto.multiply.com/attachment/ 0/SKBYWQoKCDMAAGq3h0g1/MENGENAL \%20BATIK.pdf?nmid=109927057https://huma s.sragenkab.go.id/?p=263https://www.antaran ews.com/berita/1284994512/batik-tulis-sogansampai-ke-eropa 
http://parasakti7970.blogspot.co.id/2012/03/normal0 -false-false-false-en-us-x-none.html

Yuniarti, D., Asitah, N., Nahdiyah, K., Maula, I., Munjidah, A., Sholichah, S. A., Purnomo, A., Rosyidah, E., Istiqomah, N., Anam, F., Achmadi, A. K. (2018, May 25). Batik Jetis Sidoarjo Sebagai Destinasi Ekskursi Impresif.

http://doi.org/10.17605/OSF.IO/XRY58 